\title{
Historical concept of philosophy of education
}

\section{Abstract \\ Historyczne pojęcie filozofii edukacji}

W artykule podjęto próbę historycznego ujęcia kategorii „filozofii edukacji” na podstawie analizy (z uwagi na występujące tam podobieństwa świadczące o historycznej ciągłości myśli) poglądów na edukację wybitnych filozofów. Zaproponowana w artykule analiza wybranych kontekstów historii filozofii, w których funkcjonowały omawiane pojęcia dotyczące edukacji, na pozór wydaje się prowadzić do negatywnych wyników, ponieważ w każdym z tych kontekstów zauważalny jest tylko element bądź wycinek filozofii edukacji. I tak, dla przykładu, jedni myśliciele cenili w życiu człowieka edukację etyczną, inni oddawali pierwszeństwo logicznej wiedzy, jeszcze inni filozofowie wskazywali na konieczność samopoznania lub też akcentowali istotną rolę poznania świata. W związku z tym filozofię edukacji warto utożsamiać nie z jednym konkretnym podejściem, lecz z pełnym spektrum poglądów i myśli, z uwagi na ich - do pewnego stopnia - filozoficzną komplementarność. Oznacza to, że wszystkie przejawy myślenia filozoficznego, które odnoszą się do pojęcia „edukacja”, stanowią przedmiot filozofii edukacji.

Konteksty historyczne filozofii ujawniają jedną i tę samą tendencję: pojmowanie edukacji jako intelektualnego wsparcia umożliwiającego człowiekowi dążenie do samorealizacji. Historia filozofii poucza nas, by edukacji nie ograniczać jakimikolwiek ramkami czy normami. Ważne, by właśnie w ramach edukacji akcentować konieczność stworzenia jak najlepszych możliwości rozwoju każdemu człowiekowi, by tworzyć przestrzeń dla praktyk wolności. Ludziom potrzebne jest całe życie, żeby stworzyć swój pogląd na świat i własny moralny ideał, to $z$ kolei wymaga stałego zwracania uwagi na samego siebie i umiejętności myślenia krytycznego. 
Filozofów jednoczy idea, że edukacja jest obowiązkowym fundamentem ludzkiego bytu. Nie zaprzeczając wartości poszczególnych nauk w życiu człowieka, filozofowie na przestrzeni wieków wyraźnie podkreślali, że dla wszystkich ludzi i w każdym czasie ważna jest ta nauka, która może wykształcić osobowość. Zatem filozoficzną istotą edukacji jest zbliżenie się człowieka do duchownej doskonałości.

Key words: history of philosophy, philosophy of education, the content of education, personality, values

Słowa kluczowe: historia filozofii, filozofia edukacji, treść edukacji, osobowość, wartości

1.

The concept "philosophy of education" usually covers all known achievements in philosophy concerning the fundamental problems of education. Still, is such a definition of philosophy of education adequate? Only if all these known achievements are united around the common content that defines the philosophy of education essence.

However, it is difficult to assume this since philosophy of education has changed its meaning throughout history (e.g. Curren, 2003; Phillips, Siegel, 2018). Some philosophers considered moral education to be valuable in human life, others - logical one; some philosophers believed self-knowledge the most important thing for a person, others - the outlook. Therefore, we can deal not with one philosophy of education, but with different philosophies of education. If so, then the entire history of philosophy of education does not have the necessary internal unity. This means that each of us can interpret it differently: either as an ethical education, or as a logical, and so on.

To find out whether there is a single essence of philosophy of education, one has to refer to those philosophers, who attached importance to the education issues. Such an inductive study can help to get closer in understanding the philosophy of education content, and also help to identify typical views in the history of philosophy concerning its essence.

This approach in defining philosophy of education is caused by the significant achievements in philosophy regarding the solution of the fundamental education problems, which is clearly imprinted in the human consciousness and to which we always appeal talking about philosophy of education. Socrates, Plato, Aristotle, Michel Montaigne, Immanuel Kant, Wilhelm Dilthey, John Dewey - here are some of the philosophers who can orientate us in solving the fundamental education problems. Why these philosophers? Because their views on education are versatile. In addition, they argue that only through the 
pursuit of that which is contrary to our original quest, we are able to transform ourselves and our worldviews.

Thanks to the inductive method one can also find out the differences in the various definitions of philosophy of education and explore the cultural and historical preconditions for their emergence. This will help to determine the philosophy of education scope. But most importantly, this method will assist us in identification that single content around which the considerations by prominent philosophers of education have always turned. After all, their views have never been formed in isolation, but only in the continuous unity with history.

Owing to the Greeks, we have the modern philosophy of education discus-

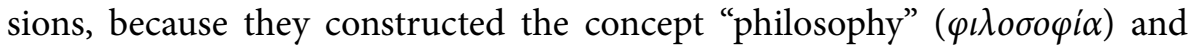

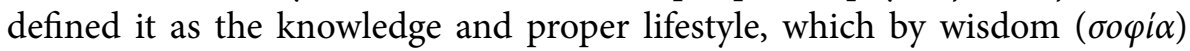
is a concern for paideia $(\pi \alpha \iota \delta \varepsilon i ́ \alpha)$ - education, manners, culture. Thus, an attempt to answer the question "What is philosophy of education?" should be preceded by an appeal to this phenomenon's origin, in particular to Socrates's, Plato's, Aristotle's works.

Socrates. The ideal of all times philosopher, future generations considered Socrates. A German scholar of the Greek paideia, Werner Jaeger, considered the fact, that the life of Socrates was a new nonpareil expression, and this was the great strength of his paideia (Jaeger, 1997, p. 74). Socrates, like most people of his era, had interest in human and especially what he considered the most important in human's life - ethical knowledge. The sophists excluded it from education, in contrary to him, since they defined only craft as wisdom. Therefore, Socrates worked only in two areas of philosophy: in the ethics and in the logic - the necessary background of ethics.

Unlike the sophists, who defined the virtue $\left(\alpha \rho \varepsilon \tau \eta^{\prime}\right)$ as a relative value, that is different for all people, Socrates argued that virtue is absolute, the same for all. In this way Socrates aimed to emphasize the moral values universality. He considered universal virtue to be the top of wealth, so he told: "in my life I did not keep quiet, but neglecting what most men care for - money-making and property, and military offices, and public speaking, and the various offices and plots and parties that come up in the state" (Plato, 1966a, 36b) and he cared only about convincing everyone: "For I tried to persuade each of you to care for himself and his own perfection in goodness and wisdom rather than 
for any of his belongings, and for the state itself rather than for its interests, and to follow the same method in his care for other things" (Plato, 1966a, 36b). Socrates could not imagine virtue without benefit and happiness, because he believed: "and I tell you that virtue does not come from money, but from virtue comes money and all other good things to man, both to the individual and to the state" (Plato, 1966a, 30b). That is why everyone's philosophizing and belief that the concern for virtue is the greatest value in life, Socrates defined valuable. According to him, it benefits all people, and also makes everyone really happy. Asserting virtue with knowledge, Socrates aimed to prove that people inadvertently act in an evil way, and they often do not realize that they are wrong. But if people had known what goodness was and realized its benefit and happiness, they would not have acted evilly. That is why the philosopher defined knowledge as virtue of goodness. Socrates believed, this knowledge is a kind of practical rationality ( $\varphi \rho o$ ov $\sigma \sigma \varsigma)$, which, like any other one, can be learned. Therefore, knowledge is not innate or something that arises by itself: a person acquires knowledge, if he or she persistently strives to do it.

According to Socrates, taking care for paideia is the human desire of benefit and happiness. Since only absolute virtue can make a person truly effective and happy, he or she needs to learn how to recognize this knowledge in himself or herself and others. Socrates tried not only to affirm his ideal of the paideia, but also to embody it in his life. Through the centuries Socrates brought the value of knowledge in itself, knowledge of which can be guaranteed only by education, the goal of which is intellectual and moral improvement, as the indestructible competition for the absolute virtue, because only this can guarantee a person the opportunity to remain himself or herself.

The idea of Socrates' paideia was in the search for knowledge, because the philosopher did not have the finished knowledge, and the show of presenting something the person does not know as his or her perfect knowledge, he considered the most shameful ignorance. Therefore, the theory of Socrates knowledge is a methodology of knowledge based on conversation - discussion. Negative method of Socratic logic consisted of bringing people to the fact that only they consider themselves as wise, but in reality they are not. Socrates argued about the fact his wisdom is at one iota deeper, because when he did not know something, then he couldn't even think he knew. That is why he believed that he was born to such irony. Knowledge of Socrates' ignorance, as claimed by a Polish historiographer Władysław Tatarkiewicz, is a psychological knowledge, because, "ascertaining his ignorance, he showed the actual knowledge of himself" (Tatarkiewicz, 2006, p. 87), but above all there was epistemological knowledge in him, "because he discovered that he knows what actually knowledge is" (Tatarkiewicz, 2006, p. 87), so that, he had the concepts and cri- 
teria of knowledge. The positive method of Socratic logic consisted of creation such questions that, through analogy, induction, and the definition of a concept, helped a person to gain true virtue knowledge. Socrates considered this method of philosophizing as the most favourable for teaching a person who aspires to virtue because, according to him, if a person has a clue about virtue, then she/he has knowledge of virtue, and if a person has knowledge of virtue, then she/he is virtuous.

The Socratic idea about the unity of knowledge, virtue and happiness laid the ethical and logical foundations of philosophy of education. Thanks to Socrates, the concept of freedom began to be viewed as a moral issue, since in antiquity, virtue was considered worthy only for a free person. It should be noted that the main thing in Socrates's paideia was appreciation of live communication. This idea was supported by his student Plato, the founder of the "Academy" philosophical school.

Plato. Plato believed that philosophy is the study of real being, which, in his opinion, can only be revealed via thinking. In the dialogue Phaedo, Plato, by the mouth of Socrates, described the term true knowledge:

Would not that man do this most perfectly who approaches each thing, so far as possible, with the reason alone, not introducing sight into his reasoning nor dragging in any of the other senses along with his thinking, but who employs pure, absolute reason in his attempt to search out the pure, absolute essence of things, and who removes himself, so far as possible, from eyes and ears, and, in a word, from his whole body, because he feels that its companionship disturbs the soul and hinders it from attaining truth and wisdom? (Plato, 1966b, 66a).

Plato considered speculative concepts to be the true mirror of being and he relied on them in his study, and the thing he thought was consistent with them, he took for truth. The philosopher's knowledge method was based on the comparison of concepts, their analysis and synthesis. In order to avoid dogmatism, Plato resorted to search for the initial position of the concept and reasoning about its consequences. But since the philosopher sought the consent of his interlocutors in caring for truth, because he was convinced that only a general view could help to consider the question under consideration, his method can be considered not only a logical but also a spiritual exercise. Obviously, this testifies to the recognition by the philosopher of thought freedom in the search for truth. At the same time, the pure evidence of the pros and cons was unacceptable to him, because then, he believed, it was not a matter of truth, but only of imposing his opinion on others.

It's the important question, what was the basis of the Plato's school unity? Pierre Hadot, a French scholar of ancient philosophy, argued that although Plato and other Academy philosophers disagreed on certain points of the doctrine, they all, more or less, shared Plato's lifestyle choices. In particular, they 
agreed about his commitment to the ethics of dialogue, because in their opinion, science itself is a virtue (Hadot, 1999, p. 77). Hadot also suggested that the Academy developed a general concept of the human formation science, a gradual and multidimensional character education, the harmonious development of the whole human personality, and finally, a way of life, designed to ensure a good life (Hadot, 1999, p. 78).

Indeed, taking into account the statement about the soul immortality, Plato believed that it required care not only in life, but also at all times. The only shelter and salvation for the soul, according to Plato, is "by becoming as good and wise as possible. For the soul takes with it to the other world nothing but its education and nurture" (Plato, 1966b, 107d). Therefore, for the sake of the soul immortality, a person should make every effort to be virtuous and prudent, "has rejected the pleasures and ornaments of the body, thinking they are alien to him and more likely to do him harm than good, and has sought eagerly for those of learning, and after adorning his soul with no alien ornaments, but with its own proper adornment of self-restraint and justice and courage and freedom and truth, awaits his departure to the other world, ready to go when fate calls him" (Plato, 1966b, 114e). Obviously, that is why in the Republic Plato noted the importance of the philosophical way of life:

And this is the chief reason why it should be our main concern that each of us, neglecting all other studies, should seek after and study this thing - if in any way he may be able to learn of and discover the man who will give him the ability and the knowledge to distinguish the life that is good from that which is bad, and always and everywhere to choose the best that the conditions allow, and, taking into account all the things of which we have spoken and estimating the effect on the goodness of his life of their conjunction or their severance, to know how beauty commingled with poverty or wealth and combined with (Plato, 1935, 10.618c).

So, the paideia's care, according to Plato, is the desire to know the real being, the mental coverage of its truth in the concept. At the same time, Plato, like Socrates, did not think about the knowledge as purely theoretical. Because knowledge is a virtue, he believed it is a prerequisite for the human creation. In this way, the paideia in Plato's understanding acquires a new philosophical and educational significance. Achieving compulsory knowledge - that is the real purpose of education. The views of Plato were developed by his outstanding student Aristotle, the founder of Lyceum school of philosophy.

Aristotle. Aristotle believed all people naturally aspire to knowledge (Aristotle, 1989, 1.980a). The ancient Greek philosopher distinguished human desire for different knowledge. For the experienced know the fact, but not the wherefore; but the artists know the wherefore and the cause. But according to Aristotle knowledge of the causes, though there is knowledge and understanding, is not wisdom. Because wisdom does not set a utilitarian purpose, it seeks 
to know first reason for their own sake, not for any benefit. Wisdom, according to him, is a universal knowledge that demands huge mental efforts and the high degree of abstraction. It should be noted that the ancient Greek philosopher believed that it is impossible for humans to possess universal knowledge: "God alone can have this privilege" (Aristotle, 1989, 1.982b). But, he was convinced that "the acquisition of this knowledge, however, must in a sense result in something which is the reverse of the outlook with which we first approached the inquiry" (Aristotle, 1989, 1.983a). So, people are concerned with the divine and can multiply it in their life: "If then the intellect is something divine in comparison with man, so is the life of the intellect divine in comparison with human life" (Aristotle, 1934, 10.7.8.). Indeed, the life that corresponds the mind makes a person happy (Honcharenko, 2017, p. 317). Thus, Aristotle lays the new foundation of philosophy of education - metaphysical.

But did Aristotle really consider happiness as the divine part or only chance in life? The philosopher used to think that happiness is the result of virtue, learning or exercises. And only in this sense he attributed it to divine and blessed. However, the philosopher claimed happiness is something common to many people, because due to learning and diligence it can belong to all. So, happiness is the harmony with human nature. Therefore, it is a mistake to entrust it to a case. Happiness is a kind of soul activity, agreed with virtue. However, Aristotle recognized both the intellectual and ethical virtues. Intellectual virtues arise through learning, and ethical - because of habit. The philosopher connected intellectual virtue with two rational abilities: scientism and prudence. Scientific skills are induction and deduction, and prudence is making right decisions in general (Honcharenko, 2017, p. 317-318).

Aristotle did not link ethical virtues with human nature, as "for no natural property can be altered by habit". Significant value in acquiring ethical virtues he gave to practice: "We learn an art or craft by doing the things that we shall have to do when we have learnt it" (Aristotle, 1934, 2. pos. 7.4.). Thus philosopher affirmed the urgent need for the development of good character through person's virtuous deeds. He believed that parents should first teach a child to behave correctly. This habit is formed unconsciously, mainly because of parents' authority. But then the child will realize the essence of virtues and will give them a preference in a situation of choice. It is essential that the ancient philosopher did not limit the formation of human character by a certain period of life because he was confident that becoming a virtuous man is a lifelong process. Therefore, Aristotle attached great importance to education, by which he meant primarily moral education. The philosopher considered education nationwide issue, which purpose is caring about the formation of a dignified citizen as the only guarantee of stability throughout the state. However, this 
does not mean that Aristotle aimed to subdue the man state. He sought a harmonious combination of human purpose and goals of the state. In his opinion, the state should create for human conditions for achieving the highest good, while the state itself reaches this good. That is why he stressed the importance of leisure in human life (Honcharenko, 2017, p. 318).

The Ancient Greek sages' interpretation of "philosophy" term is not only a theory of metaphysics, knowledge, logic and ethics but also as a living practice in these knowledge areas, became decisive for the organization of ancient philosophical schools. The concept of paideia, developed by Greek philosophers also evolved in the Stoic Philosophy of Cicero and Seneca. Cicero connected the point and all the sciences doctrine. It highlights the right path in life for a person and helps to acquire "that wisdom which is called philosophy among the Greeks" (Ciceronis, 1557, p. 9). Seneca rebuked the Ancient Roman philosophers for dissipating their wisdom into different trash - scholarism, for example, by his pedagogical maxim "We do not learn for school, but for life" (Non scholae, sed vitae discimus) (Seneca, 1999). The achievements of Cicero and Seneca gave to Wilhelm Dilthey the basement to consider the Stoic Philosophy as the most influential the world could ever create, because its "philosophical ability to form a personality" was put in the foreground (Dilthey, 1921, p. 12).

Consequently, in the classical era philosophers defined education - paideia - as the desire for knowledge for the sake of knowledge itself, regardless of its practical utility.

However, knowledge could be interpreted in different ways. Unfortunately, such considerations are disappearing in the Middle Ages, since the philosophical value of a personality formation is being replaced by the need to form a carrier of certain knowledge, depending on its practical utility.

3.

During the Renaissance, the education content of ancient philosophy was restored by a French philosopher and writer Michel de Montaigne. The philosophical and educational tradition of classical antiquity were continued by a German philosopher of the Enlightenment Immanuel Kant. A German philosopher Johann Friedrich Herbart founded pedagogy as an academic discipline giving it the philosophical foundation. One can also find reflections on philosophy as paideia in Wilhelm Dilthey's works, a German 
representative of Lebensphilosophie. This can be proved by analysis of the philosophers' views on education.

Michel de Montaigne. Montaigne determined, in harmony with the antiquity philosophers, the personal education in the full sense. He determined it as studying not for the benefit or the human eye, but to become better and smarter. And that is why he called pure bookish scholarship, after Plato, only an ornament, but not a foundation of education. According to Montaigne, this means that the student should not be taught the lessons answer as much as they are used to life.

The relativism limitations Montaigne opposed the absolutism of Socrates. He considered only the knowledge that teaches logical thinking, self-knowledge and philosophizing, because that gives a freedom to a person. Since the upbringing does not prejudge the human nature, but leads to the opposite thing, which is wisdom, then, according to Montaigne, children can be taught the philosophy, because it "has something to tell us at the dawn of life and on its slope" (Montaigne, 2005b, p. 181). The philosophy is called "to be completely involved in everything" (Montaigne, 2005b, p. 182).

As the studying basis of the philosophy of life Montaigne defined the interest. He attached the importance of this basis cultivation of the path to philosophy and a teacher should have a skill of Aristotelian clearance of the human desire to reach a certain different knowledge level and cause knowledge preference. According to Montaigne, teaching with this approach should consist in being an independent student and arming him with the knowledge method. The philosopher considered communication to be useful in such teaching. He explained this primarily by the fact that the search for truth requires a reasoned discussion, as well as a worthy philosophical conscience, which will keep a person from defending a false cause in the heat of an argument and save this person from dogmatism. At the same time, Montaigne encouraged those "who live only in the memory of books" to communicate with people (Montaigne, 2005b, p. 173).

Despite the philosophical value in human life, Montaigne recognized that in his century it even became an empty sound for intelligent people, something fantastic, "without benefit and without value, both in theory and in practice" (Montaigne, 2005b, p. 177). The philosopher connected such situation with "verbal thickets", "and the impregnable lady with a gloomy, angry and terrible face makes it difficult for children to learn" (Montaigne, 2005b, p. 177-178). Montaigne spoke about the consequences of the philosophical medieval transformation into a theology servant and the forfeit of its own existence sense. Reduced to teaching and commenting philosophy it received the name of scholasticism. This philosophy adopted only the ancient philosophy teaching 
method, but it was no longer interested in people, only attached this person to religious tenets and whether will she or he become a specialist. But Montaigne believed that in his time there are those who do not seek any benefit. Therefore, he opposed the idea that "we learn not for life, but for school" (Montaigne, 2005a, p. 156). The oeuvre of the Immanuel Kant testifies to such efforts.

Immanuel Kant. The inability of a person to use his or her own mind without someone else's guidance Kant called minority. Obviously, Kant told about the ability of a person to think critically. The philosopher considered human's abuse of natural abilities to be life-saving minorities. Minorities he contradistinguished the education with the slogan: "Have the courage to use your own mind!" (Kant, 1989, p. 135). Education in the understanding of Kant means a person's work on himself or herself and the desire for independent thinking, which as a result should help to evaluate his or her own personality and reasonably look at the vocation. The philosopher defined the condition for enlightenment as the freedom to use his or her own mind at all circumstances, because the ability to think, in his opinion, is an innate quality of a person. According to Kant, only thanks to free thought, a person is worthy of the human name; otherwise, he or she is threatened with the engine fate in the despotic authority hands. Such Kant's views can reveal a new meaning of philosophy of education - as a criticism of knowledge.

Kant's faith in the mankind spiritual progress was reflected in his pedagogical views. The philosopher argued that "human will become a human only through education" (Kant, 1803, p. 7). Kant interpreted upbringing as nursing, disciplining, and moral formation: "Infant requires a care, discipline requires an educatee, and moral education requires a pupil" (Kant, 1803, p. 1). The care means the parental tendency for their children to be not interfered with their own actions. Discipline is the way of opposition to a personal barbarism. Moral formation is the approach of human nature to become perfect. Moral education requires a distinction between a simple informant, who is a school teacher, and a teacher, who provides pedagogical guidance. If the first one teaches only for school, then the second one brings up for life.

According to the philosopher, a person can achieve the goal of his/her existence only when education is based on universal human values as the basis of equality between people. On the principles of upbringing, the thinker emphasized the harmony and purposefulness of the human natural abilities development, because he considered them a prerequisite for the development of humanity to perfection. From Kant's point of view, the content of this principle consists in the personal goodness development, since only the goodness is the happiness for a person. Kant considered upbringing as the main education principle, accordingly, not to the present, but to a more perfect future in 
accordance with the idea of humanity and its purpose as integrity. The content of this principle, according to Kant, is not to teach children the adaptation to their living conditions, but to give them a better education than the modern one, "so that the world becomes a bit possible and a bit better" (Kant, 1803, p. 17). The philosopher saw two obstacles on the way to such upbringing: "1) parents are only worried about their children being successful in life, and 2) authorities consider their subjects only as a tool for achieving their own goals. Parents worry about the family, authorities - about the state. Neither of them sets the ultimate goal of the common good and the perfection, which is the purpose of mankind and for which it has all necessary preconditions" (Kant, 1803, p. 17-18).

Kant understood that the era of morality had not yet come. His century is a century of discipline, culture and sophistication, in which the material welfare of states is inversely proportional to the human's moral poverty. The philosopher reasoned if people are not moral, then they are not happy. $\mathrm{He}$ believed that evil can be overcome only through moral education. After all, Immanuel Kant considered moral education as the greatest value in human life (Frankena, 1965, p. 100). Obviously, this Kant's point of view proves his loyalty to the classical antique ideal of philosophy as paideia.

Wilhelm Dilthey. Dilthey viewed education as a "purposeful activity, according to which adults form the spiritual life of youth" (Dilthey, 1924b, p. 69). In a broad sense, the philosopher thought of raising such a situation in which "life itself brings up a person" (Dilthey, 1924b, p. 69). For example, a priest carries out educational influence on his community, and a leader - his subordinate. At the same time, the philosopher considered education as the result of educational activities. In this sense, according to Dilthey, human is the result of nature, and humanity calls the earth his home upbringing. In a strict sense, Dilthey limited education, interpreting it as a predetermined system. Pedagogy is the knowledge of this system. But at the same time, the philosopher believed that from a philosophical point of view, education, perfection and happiness should be the ultimate goal of all institutions, and "pedagogy in this sense is a practical goal that philosophy can lead to" (Dilthey, 1924b, p. 70), which means that all educational institutions also have to recognize these goals for the ultimate and best.

The fact that education should be viewed as a goal on its own, Dilthey explained the teleological nature of spiritual life. According to him, each idea about aims and goal in itself arises only in the spiritual life, since all events in a satisfactory state of human feelings begin with it. The happiness, value, purpose and goal in themselves are determined only by this teleological attitude: "An individual cannot set that vital goal, while it's not inside his spiritual 
state" (Dilthey, 1924b, p. 70). That is why education, according to Dilthey, is an improvement of a human's spiritual life. In this regard, the philosopher highly appreciated the role of the educator, comparing his work with the genius of the artist, the purpose of which is to reveal the educatee's soul and understand it only with love for him or her.

In this context, Dilthey's "School Reforms and School Classes" (1890) deserves attention, because in it the philosopher spoke out against the pragmatical orientation of education. The scientist believed that the separation of classical and real education will lead to the dehumanization of the pedagogical process and, subsequently, to the dehumanization of society. Dilthey stressed that the school organization should be based on philosophical and historical foundations (Dilthey, 1924a), obviously, because he defined life as the cultural and historical being of human as the central pedagogical concept.

As we can see, the modern period philosophers associated opportunities of general pedagogy with classical antique meaning of philosophy as paideia. Hereby, their definition of philosophical sciences - ethics and psychology as the basis of pedagogy contributed to interpretation the latter as a part of practical philosophy.

4.

Modernity stopped associating education with satisfaction the desire for knowledge but began to link it only with benefit from knowledge. Values and benefits have become identical concepts for human, while consumption of knowledge - satisfaction of material and spiritual needs. Consequently, the idea that only pure knowledge can positively influence the personality has become more than ever relevant in the area of philosophy. In this regard, an American pragmatist John Dewey tried to overcome the dominance of conformism in education. Meanwhile, a German philosopher Theodor Adorno made efforts to resist consumerism in education.

John Dewey. As the public purpose of the school Dewey considered the life approval and the social welfare achievement. According to it, the school should provide such moral education that will allow the student to take responsibility for him and not only adapt to the future changes, but also be able to pitch and manage these changes. However, according to Dewey, the USA schools did not impose such moral responsibility on themselves, because they believed the democratic structure of the country presupposes raising a child's leadership sense and respect for the law. And that's the goal of politics and manufacture. Indeed, raising a child for a clearly established life moment in 
this world is changing rapidly and Dewey did not consider it as possible: "So far as education is conducted unconsciously or consciously on this basis, it results in fitting the future citizen for no station in life, but makes him a drone, a hanger-on, or an actual retarding influence in the onward movement. Instead of caring for himself and for others, he becomes one who has himself to be cared for" (Dewey, 1909).

As one of the most painful the education philosophy problems the scientist determined as development of teaching methodology that did not disturb the real balance between formal and non-formal education, since "When the acquiring of information and of technical intellectual skill do not influence the formation of a social disposition, ordinary vital experience fails to gain in meaning, while schooling, in so far, creates only "sharps" in learning - that is, egoistic specialists" (Dewey, 1916). Such philosopher's attitude clearly proves the value of freedom and independent thinking in human life. In this regard, Marianne Janack emphasized, Dewey's writings on education are "built upon this understanding of the interaction of human experience and the "objective" world" (Janack, 2001, p. 95).

Theodor Adorno. A German philosopher Theodor Adorno also gave a negative assessment of the education quality in the $20^{\text {th }}$ century. If on the rise of the philosophical educational idea tries to shape a person, then mass society, according to the scientist's observations, seeks only for its adjustment and adaptation. The philosopher considered a Darwinian version of education to be nothing but an ideology directed against the personal self-care. Adorno supported the point of view that education in itself can give a person something that reality can not, society only needs to give up the utility dictates in the education space, because this is the way to semi-education, in which "the educational contents survive, materialized as a commodity, that's due to their true content and lively attitude towards living subjects" (Adorno, 2017, p. 136). Adorno's philosophically educational ideas, from the perspective of a Ukrainian philosopher Maria Kultaieva, "teach us to recognize everything deformed and distorted in culture, destroys a person, opening to this human the shortest path to barbarism, but at the same time proclaims the requirement of spiritual renewal" (Kultaieva, 2017, p. 154).

It should be noted that the variable modernity has increased the philosophers' attention to the ancient paideia. For example, a French philosopher Michel Foucault sought in his studies to show that the common Greek problem was the technē of life, technē tou biou (a way of life) since ancient philosophers were interested in "which techne I must choose in order to live as I have to live" (Foucault, 2008, p. 150). In this manner the philosopher tried to prove that in antiquity, personal improvement was not determined by civil law or 
religious duty, but was an independently chosen way of existence, since it was a question of a human's transformation of own life into a special knowledge subject, techne - art. However, the idea the main art work, which needs to be dealt with, "there's me, my life, my existence" (Foucault, 2008, p. 150), has lost, according to the philosopher, significance for modern society.

This idea of Foucault is supported by a contemporary German philosopher Peter Sloterdijk. Sloterdijk draws attention to the fact that the ancient school "never considered itself as the purpose of its own activity" (Sloterdijk, 2015 , p. 105) because it worked "not for the basic camp needs, but only for the expedition" (Sloterdijk, 2015, p. 106). That is why the call "teaching for life" was at that time a password for human's achievement of something impossible - divine: "Such an equalization of God and life made it possible to build up extreme vertical tension. It made it necessary to give a radical answer to the usual ideas about the meaning of "life"' (Sloterdijk, 2015, p. 106). However, Sloterdijk agrees with Foucault and states the studying to be irrelevant for a modern person as a pure superfluity, since he or she has chosen a different guide, which is survival.

Consequently, modern education does not involve the person's preparation for life, but only adaptation to it for a brief moment. Such education can provide a person with knowledge, but it does not guarantee his or her personality growth.

5.

This research appeals to those thinkers whose works could orient in the historical definition of philosophy of education. It has shown that the concept "education" is used in several meanings in philosophy, which has contributed to the emergence of a new philosophical knowledge area in the twentieth century - philosophy of education. All manifestations of philosophical thinking regarding the education phenomenon became its subject. The analysis of philosophical and historical contexts proves that one of the meanings of education in philosophy was practical, vital. This value was given to education by Socrates, who believed that a person can become actually useful and happy only through the absolute virtue cognition in his or her soul and in others. Also, education, according to Aristotle, is the result of one of the human natural thirsts - thirst for knowledge. Another value of education goes back to Socrates', Plato's and Aristotle's definitions of philosophy as a science about the human formation and his or her way of life. The ancient Greek philosophers' 
education image was developed by Michel Montaigne, Immanuel Kant, Wilhelm Dilthey, John Dewey, Theodore Adorno and others.

If we talk in depth, the same tendency is appearing in the historical context of philosophy: the understanding of education as support person in self-realization. In the history of philosophy, there is no noticeable restriction of education by any framework or norms. There is only emphasizing the needs to create opportunities for the practice of freedom to act, because a person needs to create his or her whole life in order to form own worldview and outline own moral ideal. That demands from a person a constant attention to his or her own personality and the perfect ability to think critically. Philosophers are united by the idea that education is a human existence's indispensable foundation. That is why in different historical circumstances they were unanimous about the fact that a person needs more for life than knowledge and skills aimed to achieve certain goals, since in life he or she will also require knowledge and skills that can make this person truly happy. A philosophical reasoning's essential feature is putting emphasis on the fact that education is the process of discovering her or his own absolute values by a person and creating basis of one's own life on this knowledge, as well as the result of coordinating it with one's own life. So, the philosophical content of education is the person's approach to intellectual and moral perfection.

\section{Bibliography}

Adorno Т. (2017). The Theory of Half-education. Філособія освіти. "Philosophy of Education", no. 1 (20), p. 128-152; https://doi.org/10.31874/2309-1606-2017-20-1128-152 (accessed: 12.08.2019) [In Ukrainian].

Aristotle (1934). Nicomachean Ethics. W. Heinemann, G.P. Putnam's sons, London-New York; http://data.perseus .org/catalog/urn:cts:greekLit:tlg0086.tlg010.perseus-eng1 (accessed: 15.12.2017).

Aristotle (1989). Metaphysics. London-Cambridge; http://data.perseus.org/catalog / urn:cts:greekLit:tlg0086.tlg025 (accessed: 15.12.2017).

Ciceronis M.T. (1557). Tusculanae quaestiones. LVGDVNI, APVD IOAN. TORNAESIVM ET GVL. CAZEIVM. M. D. LVII; https://archive.org/details/bub_gb_rLVxsu8DansC/ page/n3 (accessed: 12.08.2019).

Curren R. (2003). Introduction, in: R. Curren (ed.), A Companion to Philosophy of Education. Blackwell Publishing Ltd., Oxford, UK, p. 1-4. 
Dewey J. (1909). Moral Principles in Education. Printed in the U.S.A, Cambridge, Massachusetts; http://www.gutenberg.org/files/25172/25172-h/25172-h.htm (accessed: 12.08.2019).

Dewey J. (1916). Democracy and Education; https://www.fulltextarchive.com/page/ Democracy-and-Education1/ (accessed: 10.10.2017).

Dilthey W. (1921). Das Wesen der Philosophie, in: W. Dilthey, A. Riehl, W. Wundt, H. Ebbinghaus, R. Eucken, Br. Bauch, Th. Litt, M. Geiger, T.K. Oesterreich (eds.), Systematische Philosophie, Dritte Durchgesehene Auflage, p. 1-67. Verlag und Druck von B.G. Teubner, Berlin und Leipzig; https://archive.org/details/SystematischePhilosophie/ page/n4 (accessed: 12.08.2019).

Dilthey W. (1924a). Schulreformen und Schulstuben, in: W. Dilthey, Gesammelte Schriften. Die geistige Welt: Einleitung in die Philosophie des Lebens, vol. 6, p. 83-88. Verlag von B.G. Teubner, Leipzig und Berlin; https://gallica.bnf.fr/ark:/12148/bpt6k69442d/f93. image (accessed: 12.08.2019).

Dilthey W. (1924b). Über die Möglichkeit einer Allgemeingültigen Pädagogischen Wissenschaft, in: W. Dilthey, Gesammelte Schriften. Die geistige Welt: Einleitung in die Philosophie des Lebens, vol. 6, p. 56-82. Verlag von B.G. Teubner, Leipzig und Berlin; https://gallica.bnf.fr/ark:/12148/bpt6k69442d/f66.image (accessed: 12.08.2019).

Foucault M. (2008). About Genealogy of Ethics: Review of Current Work. "Logos", no. 2 (65), p. 135-158; http://www.intelros.ru/pdf/logos_02_2008/06.pdf (accessed: 12.08.2019) [In Russian].

Frankena W. (1965). Three Historical Philosophies of Education. Aristotle, Kant, Dewey. Scott, Foresman and Company, Chicago-Atlanta-Dallas-Palo Alto-Fair Lawn-New York; https://archive.org/details/WilliamFrankena1965ThreeHistoricalPhilosophiesOfEducationAristotleKantDewey (accessed: 12.08.2019).

Hadot P. (1999). What is Ancient Philosophy?. Humanitarian literature publishing, Moscow [In Russian].

Honcharenko O. (2017). Yakym Yarema's Philosophical and Pedagogical Ideas in Discursive Practices of Education. "Kultura - Społeczeństwo - Edukacja", no. 2 (12), p. 313-327. doi 10.14746/kse.2017.12.15.

Jaeger W. (1997). Paideia. The Ideals of Greek Culture. "Greec-Latin cabinet” Y.A. Shichalina, Moscow [In Russian].

Janack M. (2001). Dewey, John, in: E.V. Taylor, C.E. Winquist (eds.), Encyclopedia of Postmodernism. Routledge, London-New York, p. 94-95.

Kant I. (1803). Über Pädagogik. Friedrich Nicolovius, Königsberg; https://archive.org/ details/berpdagogik00kant/page/n2 (accessed: 12.08.2019).

Kant I. (1989). An Answer to the Question: What is Enlightenment? "Universe", no. 4, p. 135-138 [In Ukrainian]. 
Kultaieva M. (2017). The Education and its Deformations in the Contemporary Culture: A Contribution to the Actuality Theodor W. Adorno's Theory of Half-educaton. “Філософія освіти. Philosophy of Education”, no. 1 (20), p. 153-195. doi https:// doi.org/10.31874/2309-1606-2017-20-1-153-195 [In Ukrainian].

Montaigne M. (2005a). On the Education of Children, in: M. Montaigne, Essais. Book first. DUKH I LITERA, Kyiv, p. 161-196 [In Ukrainian].

Montaigne M. (2005b). About bakaliarstvo, in: M. Montaigne, Essais. Book first. DUKH I LITERA, Kyiv, p.149-160 [In Ukrainian].

Phillips D.C., Siegel H. (2018). Philosophy of Education, in: E.N. Zalta (ed.), Stanford Encyclopedia of Philosophy; https://plato.stanford.edu/entries/education-philosophy/ (accessed: 12.08.2019).

Plato (1935). Republic. Plato in Twelve Volumes, vols. 5-6. Harvard University Press, W. Heinemann Ltd., Cambridge, Mass-London; http://catalog.perseus.org/catalog/ urn:cts:greekLit:tlg0059.tlg030.perseus-eng1 (accessed: 10.10.2018).

Plato (1966a). Apology. Plato in Twelve Volumes, vol. 1. Harvard University Press, W. Heinemann Ltd., Cambridge, Mass-London; http://catalog.perseus.org/catalog/ urn:cts: greekLit:tlg0059.tlg002.perseus-eng1 (accessed: 10.10.2018).

Plato (1966b). Phaedo. Plato in Twelve Volumes, vol. 1. Harvard University Press, W. Heinemann Ltd., Cambridge, Mass-London; http://catalog.perseus.org/catalog/ urn:cts: greekLit:tlg0059.tlg004.perseus-eng1 (accessed: 10.10.2018).

Seneca (1999). Moral Letters to Lucilius. Osnovy, Kyiv; http://ae-lib.org.ua/texts/ seneca_ad_lucilium_epistularum_moralium_ua.htm (accessed: 12.10.2018) [In Ukrainian].

Sloterdijk P. (2015). You Must Change Your Life (excerpts of work). "Philosophical Thought", no. 2, p. 95-106 [In Ukrainian].

Tatarkiewicz W. (2006). History of Philosophy, vol. 1: Ancient Philosophy and Medieval Philosophy. Svichado, Lviv [In Ukrainian]. 